Vol. 2, No. 1, Juni 2017, pISSN 2527-2853, eISSN 2549-2985

\title{
Kajian Penerapan Ergonomi dalam Perancangan Bangunan Sekolah Dasar, Studi Kasus SDN Bubutan IV Surabaya
}

\author{
Lea Kristina Anggraeni \\ Dosen Jurusan Desain Interior, FTSP, Institut Teknologi Sepuluh Nopember Surabaya \\ leaanggraeni@yahoo.com
}

\begin{abstract}
ABSTRAK
Alasan orang tua memilih sekolah yang baik, sering diukur dengan fasilitas dan prestasi sekolah tersebut. Orang tua sering memilih untuk menyekolahkan di sekolah swasta atau sekolah negeri favorit, meskipun lokasinya jauh dari rumah mereka. Pemerintah Kota Surabaya mengembangkan program SDN Merger sebagai solusi dari permasalahan tersebut. SDN Merger merupakan program penggabungan dua atau lebih sekolah dasar negeri yang memiliki lokasi saling berdekatan dan kekurangan murid. Tujuan utama dari program ini adalah untuk meningkatkan kualitas sarana dan prasarana, dan mendorong tercapainya prestasi bagi siswa, guru dan sekolah itu sendiri.

Perencanaan pembangunan gedung sekolah dasar SDN Bubutan IV memperhatikan 3 faktor utama, yaitu : 1) Faktor manusia sebagai pengguna, khususnya siswa SD dengan rentang usia 6 - 12 tahun, menggunakan pendekatan ergonomi dan antropometri, 2) Faktor lingkungan sekitar, untuk dapat mengoptimalkan lingkungan sebagai penunjang kegiatan belajar mengajar; dan 3) Faktor kebijakan pemerintah yang berlaku seperti tertulis pada Peraturan Menteri Pendidikan Nasional RI Nomor 24 tahun 2007 tentang Standar Sarana dan Prasarana Untuk Sekolah Dasar/Madrasah Ibtidaiyah (SD/MI), Sekolah Menengah Pertama/Madrasah Tsanawiyah (SMP/MTs) dan Sekolah Menengah Atas/Madrasah Aliyah (SMA/MA).

Perencanaan pembangunan mengoptimalkan penggunaan lahan untuk memenuhi kebutuhan kelas, area terbuka sebagai sarana bermain dan olah raga, organisasi ruang dan KM/WC, keamanan siswa dalam beraktifitas dan meningkatkan kosentrasi belajar siswa, serta pemanfaatan sinar matahari sebagai penunjang pencahayaan alami.
\end{abstract}

Kata kunci: Ergonomi; SDN Bubutan IV Surabaya; Standarisasi Bangunan SD

\section{ABSTRACT}

The parents reason to choose a good school are often measured by the facilities and the achievement. They often choose a non public school or the favourite public school eventhough far away from their homes. The Surabaya's City Government has developed a program to resolve this problem, it's called SDN Merger. As the name implies, the program is merged some elementary public school which near to each other and few students become one public school. The main purpose of this program are to developed the school facilities and encourage achievement of students, teachers and the public school itself.

The planning construction of elementary public school SDN Bubutan IV Surabaya, based on 3 factors, are : 1) human factor as user, especially elementary school students with age range 6-12 years, using ergonomic and anthropometry approach, 2) environmental factors, to be able to optimize environment as Supporting teaching and learning activities; And 3) prevailing government policy factors as written in the Minister of National Education Regulation No. 24 of 2007 on Standards of Facilities and Infrastructure for Primary Schools / Elementary Schools (SD / MI), Junior High Schools / Madrasah Tsanawiyah (SMP / MTs) and Senior High School / Madrasah Aliyah (SMA / MA).

The planning construction of elementary public school SDN Bubutan IV Surabaya, optimized land used to set up the needs of the classes, open area as playground and sports activities, lay out for organization room, students safety and improve student's concentration also used natural lighting to support the classroom lighting. 
Lea Kristina Anggraeni

Kajian Penerapan Ergonomi dalam Perancangan Bangunan Sekolah Dasar, Studi Kasus SDN Bubutan IV

Surabaya

Keyword :Ergonomic; SDN Bubutan IV Surabaya; Elementary building standaritation

\section{PENDAHULUAN}

SDN Bubutan IV Surabaya adalah sekolah negeri yang terletak di Jalan Semarang No. 90 Surabaya. Sekolah Dasar ini terletak di kawasan perekonomian jalan Semarang dan perkampungan penduduk. Pada lokasi ini, selain SDN Bubutan IV juga merupakan lokasi 4 sekolah dasar yang lain, yaitu SDN Bubutan V, SDN Bubutan VI, SDN Bubutan VII, dan SDN Bubutan XI. Kondisi fisik bangunan SDN Bubutan IV pada saat survey tahun 2008 sudah mengalami kerusakan. Kondisi ini seringkali menjadi alasan orangtua untuk tidak mendaftarkan putra/putrinya bersekolah disini, dan lebih memilih untuk mendaftarkan di sekolah lain yang lebih favorit dan memiliki bangunan lebih baik sekalipun lebih jauh dari tempat tinggalnya. Dinas Pendidikan Kota Surabaya pada tahun 2007 mencanangkan program SDN Merger, dimana SD Negeri yang berada dalam satu kawasan/komplek menjadi pilihan utama bagi warga disekitarnya. Berdasarkan kecenderungan diatas maka salah satu upaya meningkatkan kualitas pendidikan adalah dengan memberikan sarana dan prasarana yang memadai.

Fisik bangunan sekolah negeri di kota Surabaya bila dibandingkan dengan sekolah swasta pada umumnya, masih sederhana dan terkesan kurang menarik. Baik dan buruknya sekolah seringkali dikaitkan dengan tampilan fisik dan sarana prasarana bangunannya. Perencanaan pembangunan SDN Bubutan IV Surabaya didesain untuk mengikis paradigma tersebut dengan konsep modern, memperhatikan ergonomi penggunanya, ergo-enviroment lingkungan sekitarnya dan Peraturan Menteri Pendidikan Nasional RI Nomor 24 tahun 2007 tentang Standar Sarana dan Prasarana Untuk Sekolah Dasar/Madrasah Ibtidaiyah (SD/MI), Sekolah Menengah Pertama/Madrasah Tsanawiyah (SMP/MTs) dan Sekolah Menengah Atas/Madrasah Aliyah (SMA/MA). Perancangan pembangunan sarana fisik gedung SDN yang memperhatikan masterplan, desain fasade dan fungsi bangunan.

\section{METODOLOGI}

Perencanaan bangunan fisik SDN Bubutan IV Surabaya menggunakan metode kualitatif, dengan melakukan wawancara kepada pihak sekolah. Selanjutnya melakukan pengukuran lokasi eksisting dan penggambaran ulang. Studi literasi mengenai ergonomi dan ergoenvironment serta Permendiknas RI No. 24 Tahun 2007. Hasil desain perencanaan di visualisasikan dalam gambar perspektif 3D.

Wawancara kepada pihak sekolah dilakukan untuk mengetahui permasalahan, harapan dan kebutuhan dari sekolah tersebut. Setelah melakukan wawancara, perencana melakukan pengukuran dilapangan untuk mengetahui betul bentuk dan ukuran eksisting bangunan. Hal ini sangat diperlukan untuk memberikan informasi luas lahan yang dapat digunakan dan konsep tahapan pembangunan yang sesuai dengan masterplan. Data pengukuran selanjutnya digambar ulang dengan program AutoCad 2D dan dicocokan dengan foto eksisting dan gambar citra satelit. Studi literasi difokuskan pada studi yang dapat mendukung kenyamanan dan keamanan bagi pengguna bangunan, memenuhi kebutuhan dan harapan dari kepala sekolah dengan optimal. Desain yang telah dirancang di visualisasikan dalam gambar perspektif 3D. Gambar perspektif 3D meliputi tampak masterplan dan fasade bangunan.

\section{KAJIAN LITERATUR}

\section{A. SDN Bubutan IV Surabaya}


SDN Bubutan IV Surabaya berlokasi di Jl. Semarang No. 90 Surabaya, Kecamatan Bubutan. Pada saat survey tahun 2008, lokasi merupakan kumpulan dari 5 sekolah dasar, yaitu SDN Bubutan IV, SDN Bubutan V, SDN Bubutan VI, SDN Bubutan VII dan SDN Bubutan XI. Pada saat proses perencanaan pembangunan Gedung, perencana telah mempertimbangkan peningkatan jumlah guru, staff tata usaha dan siswanya. Perencanaan ruang kelas mempertimbangkan pagu siswa tiap tahunnya, dan diperkirakan sekitar 4 kelas, dimana jumlah siswanya maksimal 40 siswa/kelas.

Berdasarkan data verifikasi tahun 2016 SDN Bubutan IV Surabaya memiliki 36 orang guru, 5 orang tenaga pendidik/staff TU, 26 rombongan belajar dengan jumlah siswa sekitar 987 siswa. Sekolah ini memiliki 28 ruang kelas, 3 ruang laboratorium, 2 ruang perpustakaan, 4 ruang sanitasi guru dan 4 ruang sanitasi siswa (Kemdikbud, Pemkot Surabaya, 2016).

\section{B. Ergonomi dan Lingkungan Sekitar}

1. Ergonomi dan Antropometri

Penekanan ergonomi dan antropometri pada bangunan sekolah dasar mempertimbangkan kepada kelompok pengguna utamanya, dalam hal ini adalah siswa. Siswa di SDN Bubutan IV Surabaya, berusia sekitar 7 - 12 tahun, berjenis kelamin lakilaki dan perempuan. Studi literasi ergonomi dan antropometri diperlukan untuk dapat menentukan standar ukuran ruang dan furnitur penunjang yang mampu mendukung proses belajar mengajar.

Tabel 1. menjelaskan bahwa pada usia 12 tahun, anak perempuan cenderung lebih tinggi daripada anak laki-laki [2]. Anak perempuan mengalami pubertas lebih awal dari laki-laki, sehingga perkembangan fisik mereka lebih cepat dan cenderung lebih tinggi dari anak laki-laki. Data yang dipakai merupakan standar Eropa, maka penyesuaian/koreksi dimensi untuk anak-anak di Indonesia menggunakan percentile 50\%.

Tabel 1. Data perkiraan antropometri untuk anak-anak di Inggris

\begin{tabular}{|c|l|c|c|c|c|}
\hline \multirow{2}{*}{ No. } & \multicolumn{1}{|c|}{ Dimensi } & \multicolumn{2}{c|}{$\begin{array}{c}\text { 7 Tahun } \\
\text { (50\%) - mm }\end{array}$} & \multicolumn{2}{c|}{$\begin{array}{c}\text { 12 Tahun } \\
\text { (50\%ile) - mm }\end{array}$} \\
\cline { 3 - 6 } & & Laki-laki & Perempuan & Laki-laki & Perempuan \\
\hline 1. & Tinggi badan & 1230 & 1220 & 1490 & 1500 \\
\hline 2. & Tinggi pandangan mata & 1115 & 1105 & 1375 & 1385 \\
\hline 3. & Tinggi badan saat duduk & 665 & 660 & 765 & 775 \\
\hline 4. & Tinggi pandangan mata saat & 550 & 555 & 650 & 665 \\
\hline
\end{tabular}

Sumber : Pheasant (2003)

Kroemer menyatakan bahwa perkembangan anak-anak pada usia 7 - 12 tahun selain pertumbuhan fisik, kemampuan motorik mereka juga semakin meningkat. Mereka semakin memiliki ketepatan dan kekuatan dalam berlari dan melompat [3]. Pada beberapa anak yang tidak suka beraktifitas fisik, cenderung mengalami obesitas. Tingkat konsentrasi anak masih belum optimal, namun anak sudah dapat fokus pada satu aktifitas lebih dari 30 menit. Berdasarkan data tersebut, apabila ada aktifitas diluar kelas, anak memiliki kecenderungan untuk melihat keluar. Kecenderungan lain adalah cara duduk anak pada saat belajar adalah setengah duduk, duduk bersandar dan berdiri. Pada duduk dengan posisi berdiri, anak sering melihat keluar dan kehilangan konsentrasi belajarnya. 


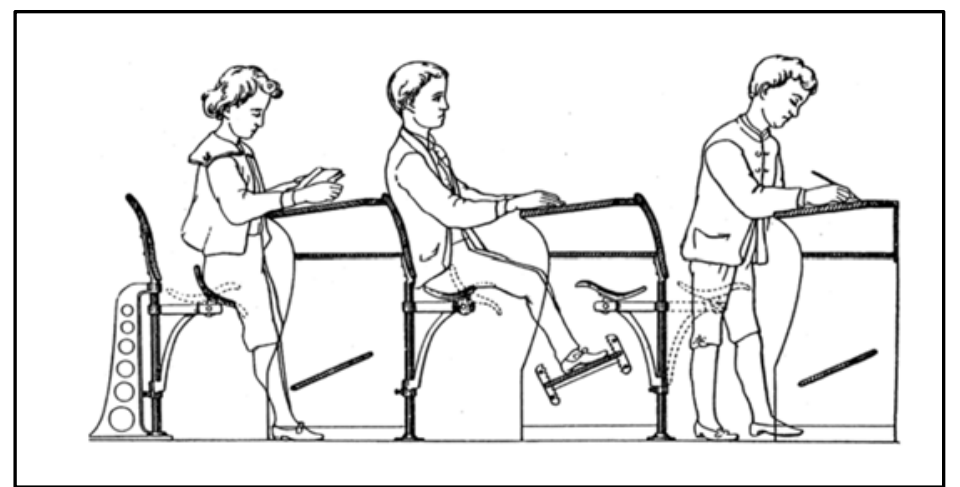

Gambar 1. Postur tubuh siswa SD saat belajar, setengah duduk (kiri), duduk bersandar (tengah) dan berdiri (kanan).

Sumber: Kroemer (2006)

2. Lingkungan Sekitar

Analisa lingkungan sekitar sering juga disebut dengan ergo-environment. SDN Bubutan IV Surabaya, berlokasi di Jl. Semarang No. 90 Surabaya, Kecamatan Bubutan. Sekolah Dasar ini terletak di kawasan perekonomian jalan Semarang dan perkampungan penduduk. Pada sisi utara bersebelahan dengan Dinas Cipta Karya dan Tata Ruang Kota Pemkot Surabaya, sisi selatan dibatasi sungai kecil adalah kawasan pemukiman penduduk. Sisi timur merupakan bangunan perkantoran dan sisi barat adalah akses jalan utama padat kendaraan baik roda 4 maupun roda 2, sehingga tingkat kebisingan cukup tinggi. Sinar matahari tidak terhalang oleh bangunan di kanan kiri nya, sehingga udara cukup kering dan suhu relatif panas, namun pencahayaan alami dapat dimaksimalkan. Kebanyakan siswa bersekolah menggunakan sepeda, berjalan kaki dan diantar orangtuanya sampai di depan pagar sekolah. Seperti sekolah negeri pada umumnya, di luar gerbang sekolah dipadati oleh PKL makanan.

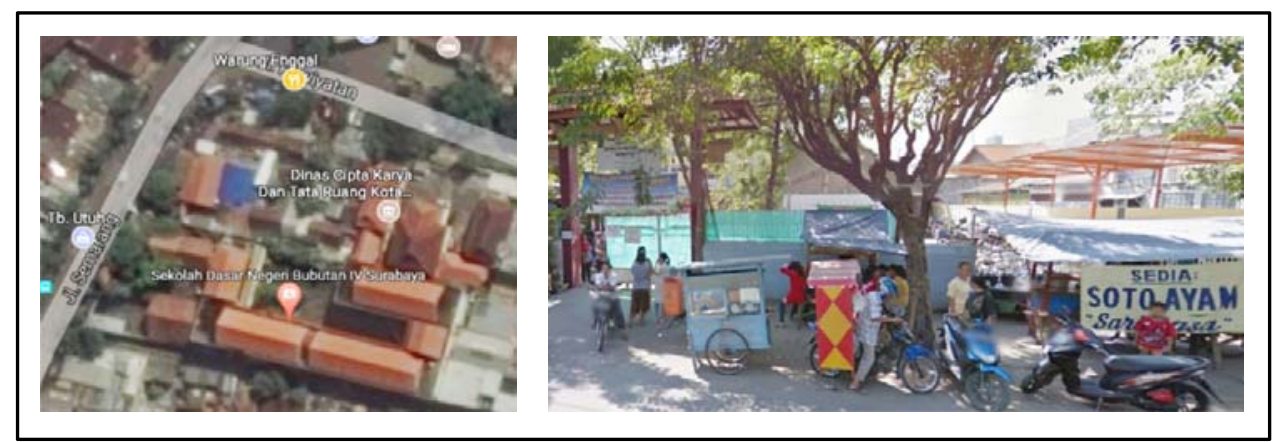

Gambar 2. Site plan SDN Bubutan IV Surabaya (kiri) dan PKL makanan di sepanjang gerbang sekolah (kanan).

Sumber: Citra satelit google map (November 2015)

\section{Peraturan Menteri Pendidikan Nasional RI Nomor 24 tahun 2007}

Peraturan Menteri Pendidikan Nasional RI Nomor 24 tahun 2007 tentang Standar Sarana dan Prasarana Untuk Sekolah Dasar/Madrasah Ibtidaiyah (SD/MI), Sekolah Menengah Pertama/Madrasah Tsanawiyah (SMP/MTs) dan Sekolah Menengah Atas/Madrasah Aliyah (SMA/MA), menegaskan bahwa terdapat standar nasional indonesia untuk bangunan sarana 
dan prasarana pendidikan. Standar ini juga dipakai untuk menjadi acuan dalam perencanaan. Beberapa standar yang dipakai antara lain meliputi (Kementrian Pendidikan, RI, 2007):

1. Lahan terhindar dari pencemaran udara dan kebisingan (h.1),

2. Memiliki struktur yang stabil dan kokoh, dan dapat bertahan hingga 20 tahun (h.3),

3. Bangunan gedung maksimum terdiri dari tiga lantai, dilengkapi tangga yang mudah diakses (h.3),

4. Bangunan memiliki prasarana ruang kelas, ruang perpustakaan, laboratorium, ruang pimpinan, ruang guru, ruang UKS, ruang ibadah, sanitasi, gudang, sirkulasi, area bermain/berolahraga (h.4),

5. Rasio minimum luas ruang kelas adalah $2 \mathrm{~m}^{2} /$ peserta didik, dengan kapasitas maksimum 28 peserta didik (h.4),

6. Lebar koridor minimum 1,8 m dengan tinggi minimum 2,5 m. Koridor di lantai 2 dan 3 dilengkapi pagar pengaman dengan tinggi $90-110 \mathrm{~cm}$ (h.13),

7. Bangunan bertingkat di lengkapi dengan tangga. Apabila panjangnya lebih dari $30 \mathrm{~m}$, maka di lengkapi minimum dua buah tangga dan jarak tempuh terjauh tidak lebih dari $25 \mathrm{~m}$. Lebar minimum tangga 1,5 m, tinggi maksimum anak tangga $17 \mathrm{~cm}$, lebar anak tangga 25$30 \mathrm{~cm}$, dan dilengkapi pegangan tangan yang kokoh dengan tinggi 85-90 (h.13),

8. Terdapat tempat bermain/olahraga yang lokasinya tidak mengganggu proses pembelajaran di kelas, dengan luas minimum $500 \mathrm{~m} 2$. Di dalam luasan tersebut terdapat ruang bebas tempat untuk berolahraga berukuran $20 \mathrm{~m}$ x $15 \mathrm{~m}$ (h.13).

\section{HASIL DAN PEMBAHASAN}

\section{A. Gambar Eksisting}

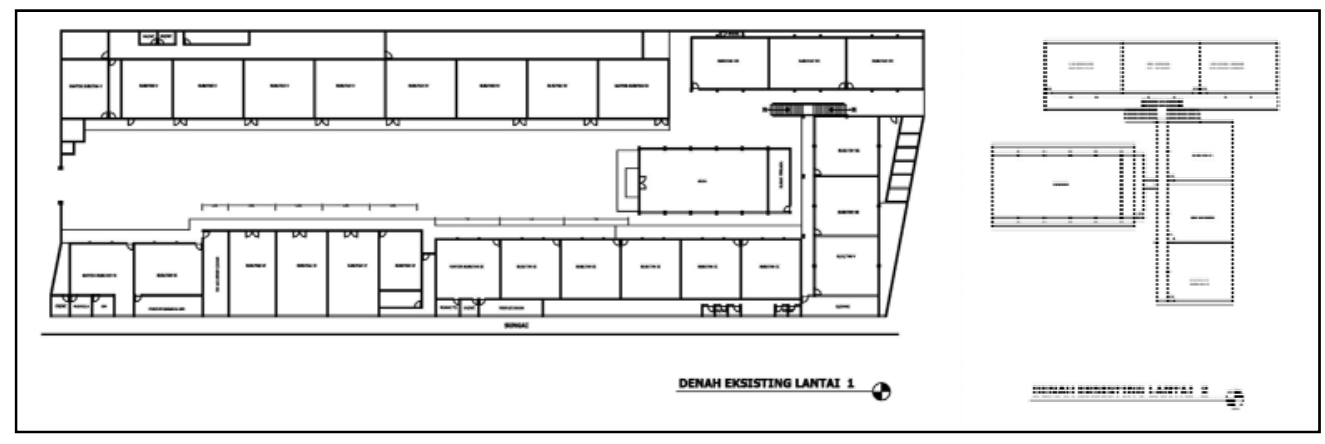

Gambar 3. Lay out eksisting SDN Bubutan IV Surabaya Sumber : Dokumen pribadi (2008)

Bangunan eksisting membentuk huruf U memenuhi seluruh lahan. Area untuk bermain dan berolahraga ada tepat di depan kelas, sehingga dapat mengganggu aktifitas di dalam kelas. Ukuran luas kelas sangat bervariasi dan banyak lorong. Semakin dekat bangunan dengan gerbang semakin besar tingkat kebisingan. Siteplan bangunan belum tertata dengan rapi, sehingga pengembangan bangunan baru kurang efektif.

\section{B. Konsep Desain}

Berdasarkan studi literatur dan wawancara dengan pihak sekolah saat itu, diperoleh konsep desain Gedung SDN Bubutan IV Surabaya, yaitu : 
1. Bangunan dirancang 3 lantai dengan struktur bangunan menggunakan beton readymix K300. Perencanaan struktur telah diuji menggunakan software SAP, sehingga dipastikan kokoh dan stabil, mampu menahan gerakan vertikal dan horisontal.

2. Mendesain ruang kelas dengan kapasitas 32 siswa, dengan lay out meja kursi berbentuk seminar dan berkelompok.

3. Mengatasi tingkat konsentrasi siswa yang mungkin terganggu apabila ada aktifitas di luar kelas, maka di desain jendela diatas tinggi kepala siswa saat duduk, setinggi $110 \mathrm{~cm}$ dari permukaan lantai. Desain ini memiliki kelebihan, siswa tidak dapat melihat keluar, namun dari luar tetap dapat melihat dan mengawasi kegiatan di dalam kelas. Dinding dibawah jendela dapat digunakan sebagai tempat menempelkan karya dan tugas. Siswa dapat dengan mudah menempel di dinding karena tingginya masih dalam jangkauan tangan anak usia $7-12$ tahun. Selain itu, sinar matahari dapat masuk ke dalam ruang kelas, sehingga pemakaian lampu pada siang hari dapat dikurangi.

4. Pintu masuk kelas juga di desain dengan menyediakan kaca mati sebagai sarana untuk melihat ke dalam kelas tanpa harus mengganggu proses belajar siswa.

5. Pagar pembatas di lantai dua dan tiga dibuat dari dua material, dinding tembok bata setinggi $70 \mathrm{~cm}$ dan railing besi setinggi $35 \mathrm{~cm}$. Total tinggi pagar adalah $105 \mathrm{~cm}$. Pemilihan material dinding bata, dikarenakan karakter anak-anak yang gemar berlarian dan memanjat railing. Bagi anak usia 7 tahun, posisi dinding bata setinggi $70 \mathrm{~cm}$ berada diatas panggul anak dan total tinggi $105 \mathrm{~cm}$ masih diatas dada anak. Pada usia 12 tahun, tinggi panggul mereka sudah mencapai 79,8 cm dan tinggi dada mereka dari lantai mencapai 112,6 cm [5]. Tingkat keamanan lebih tinggi bagi anak usia 7 tahun. Sekalipun tinggi railing kurang dari tinggi dada anak usia 12 tahun, namun diyakini pada usia ini anak memiliki tingkat kedewasaan dan rasa berhati-hati lebih dari anak usia 7 tahun.

6. Jarak pintu gerbang dan gedung utama di desain relatif jauh, sehingga dapat mengurangi permasalahan kebisingan dan ketersediaan lahan parkir bagi guru dan siswa.

\section{Gambar Desain Perencanaan}

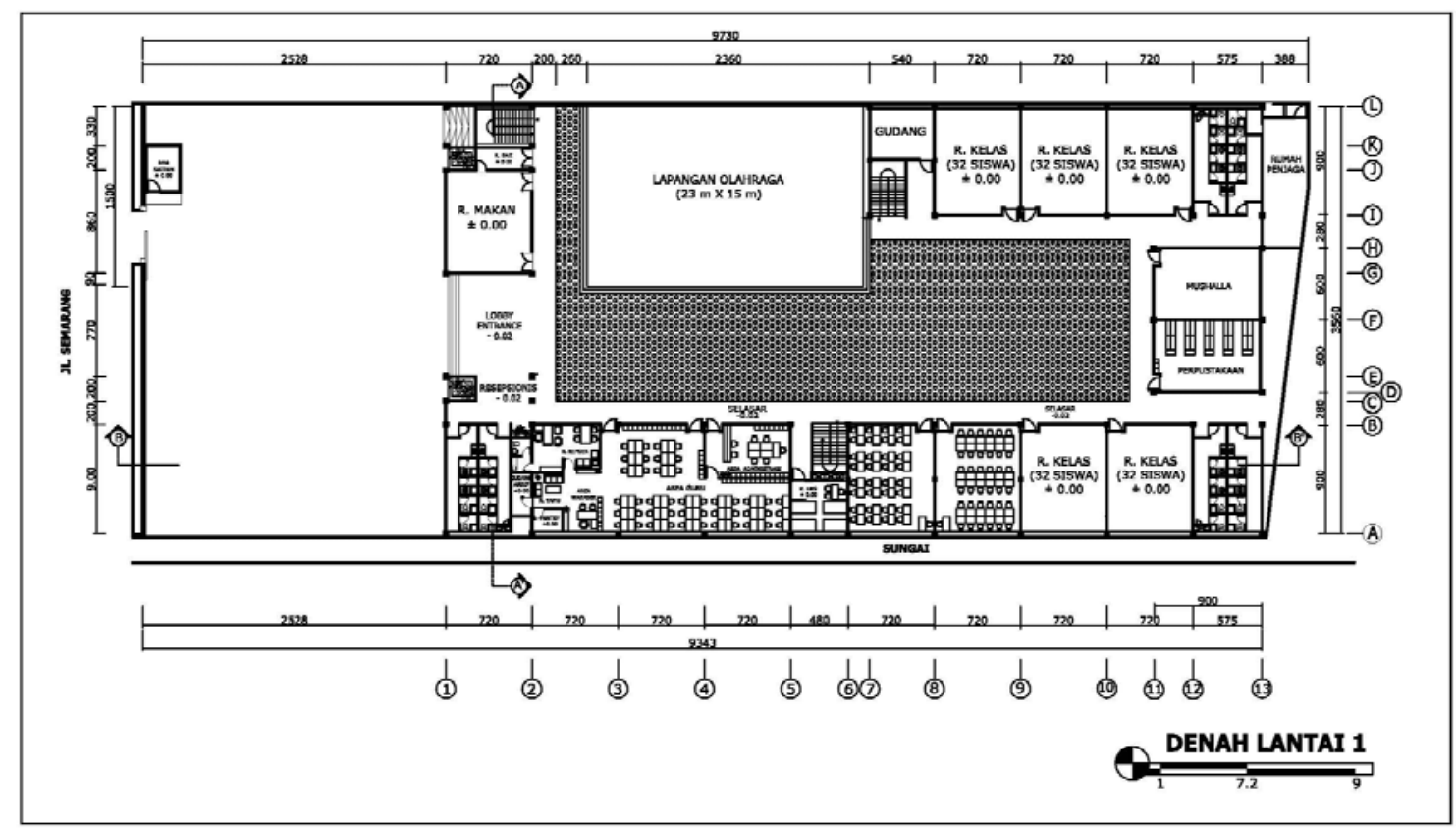

Gambar 4. Lay out perencanaan lantai 1. Sumber: Dokumen pribadi (2008) 


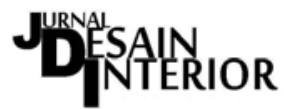

Vol. 2, No. 1, Juni 2017, pISSN 2527-2853, eISSN 2549-2985

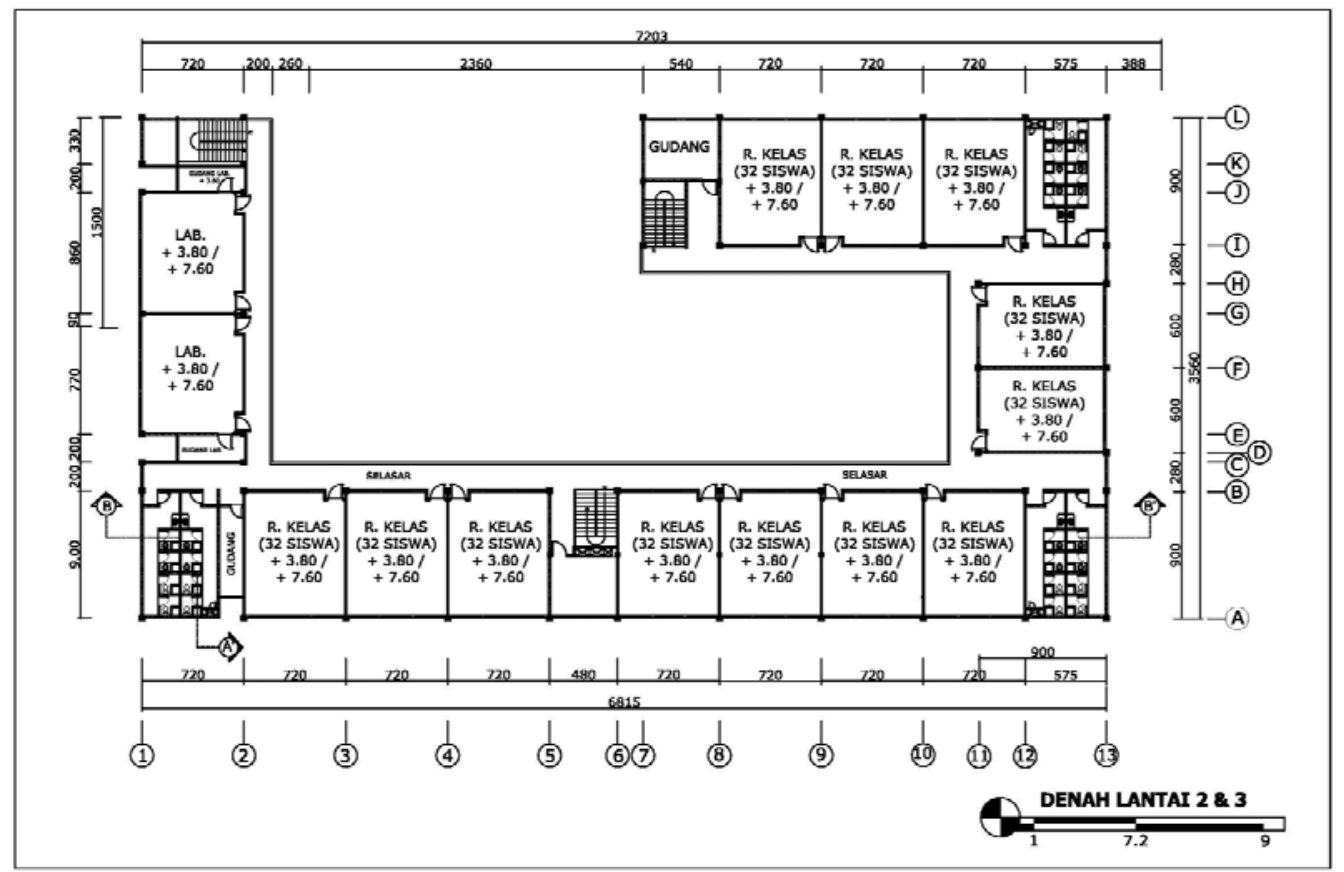

Gambar 5. Lay out perencanaan lantai 2 dan lantai 3. Sumber: Dokumen pribadi (2008)

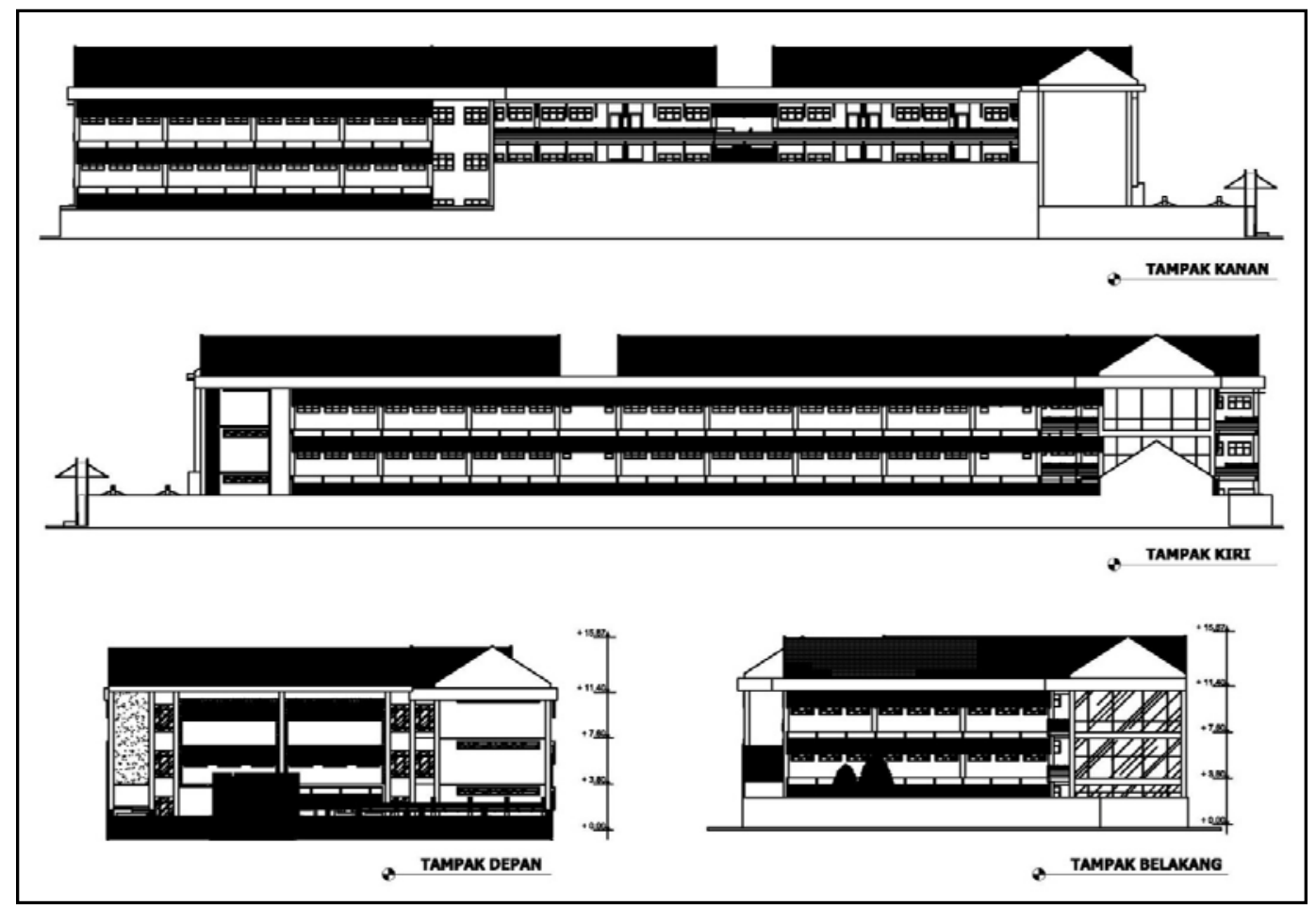

Gambar 6. Gambar tampak perencanaan.

Sumber: Dokumen pribadi (2008) 
Lea Kristina Anggraeni

Kajian Penerapan Ergonomi dalam Perancangan Bangunan Sekolah Dasar, Studi Kasus SDN Bubutan IV Surabaya

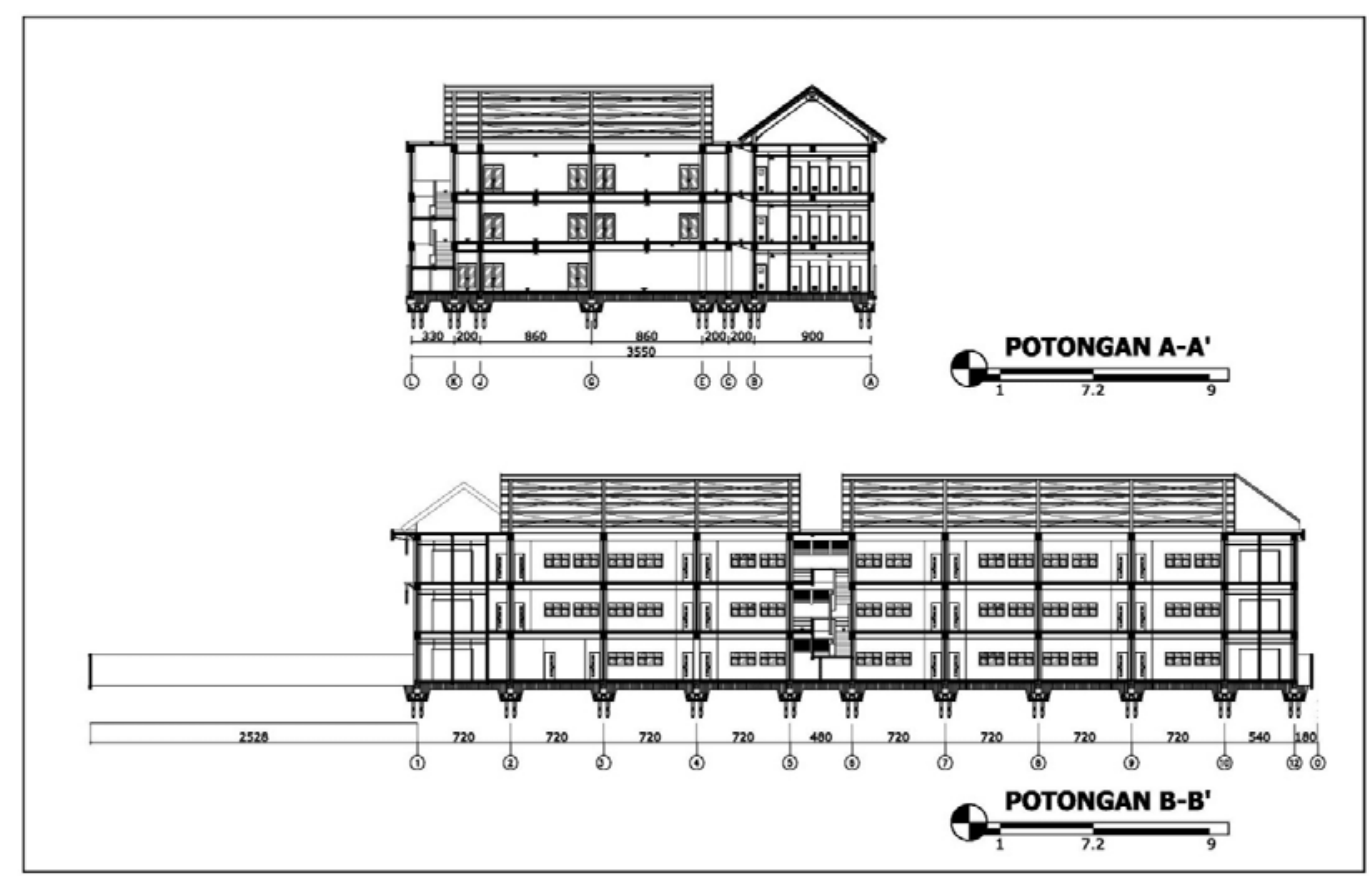

Gambar 7. Gambar potongan memanjang dan melintang. Sumber: Dokumen pribadi (2008)

Keterbatasan lahan dapat diatasi dengan merencanakan pembangunan gedung tiga lantai. Perencanaan gedung yang baru memberikan fasilitas yang lebih baik dari sisi jumlah ruang, luasan dan fasilitas penunjang. Perbandingan sarana dan prasarana gedung eksisting dan perencanaan dapat dilihat pada Tabel 2.

Tabel 2. Perbandingan sarana dan prasarana eksisting dan perencanaan yang baru

\begin{tabular}{|c|c|c|c|c|}
\hline No. & Nama Ruangan & $\begin{array}{c}\text { Lama - } \\
\text { Survey } \\
\text { Lapangan / } \\
\text { Luas }\left(\mathbf{m}^{2}\right)\end{array}$ & $\begin{array}{c}\text { Baru - Desain } \\
\text { Perencanaan / } \\
\text { Luas }\left(\mathbf{m}^{2}\right)\end{array}$ & $\begin{array}{c}\text { Kapasitas } \\
\text { (Baru) }\end{array}$ \\
\hline 1. & Kelas & 29 / @ 55 & $31 / @ 65 \mathrm{~m}^{2}$ & 32 siswa + 1 Guru \\
\hline 2. & Ruang Kepsek, Wakasek dan Guru & $4 / @ 56$ & $1 / 170$ & 47 guru \\
\hline 3. & Ruang Tata Usaha & 4/@12 & $1 / 32$ & 7 Tenaga Pendidik \\
\hline 4. & Ruang Laboratorium & 2 /@54 & 4/@62 & 32 siswa +1 guru \\
\hline 5. & Ruang Perpustakaan & 4/@14 & $1 /$ @54 & 32 siswa +1 staff \\
\hline 6. & Mushola & 1/@108 & 1/@54 & 33 jamaah \\
\hline 7. & Area Olahraga/Bermain & $1 / 710$ & $1 / 930$ & \\
\hline 8. & Sanitasi & 17 /@6,5 & 3/@46 & 48 siswa +8 guru \\
\hline
\end{tabular}

Sumber : Data Pribadi (2008) 


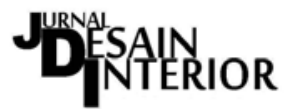

Vol. 2, No. 1, Juni 2017, pISSN 2527-2853, eISSN 2549-2985

\section{Gambar Perspektif 3D}
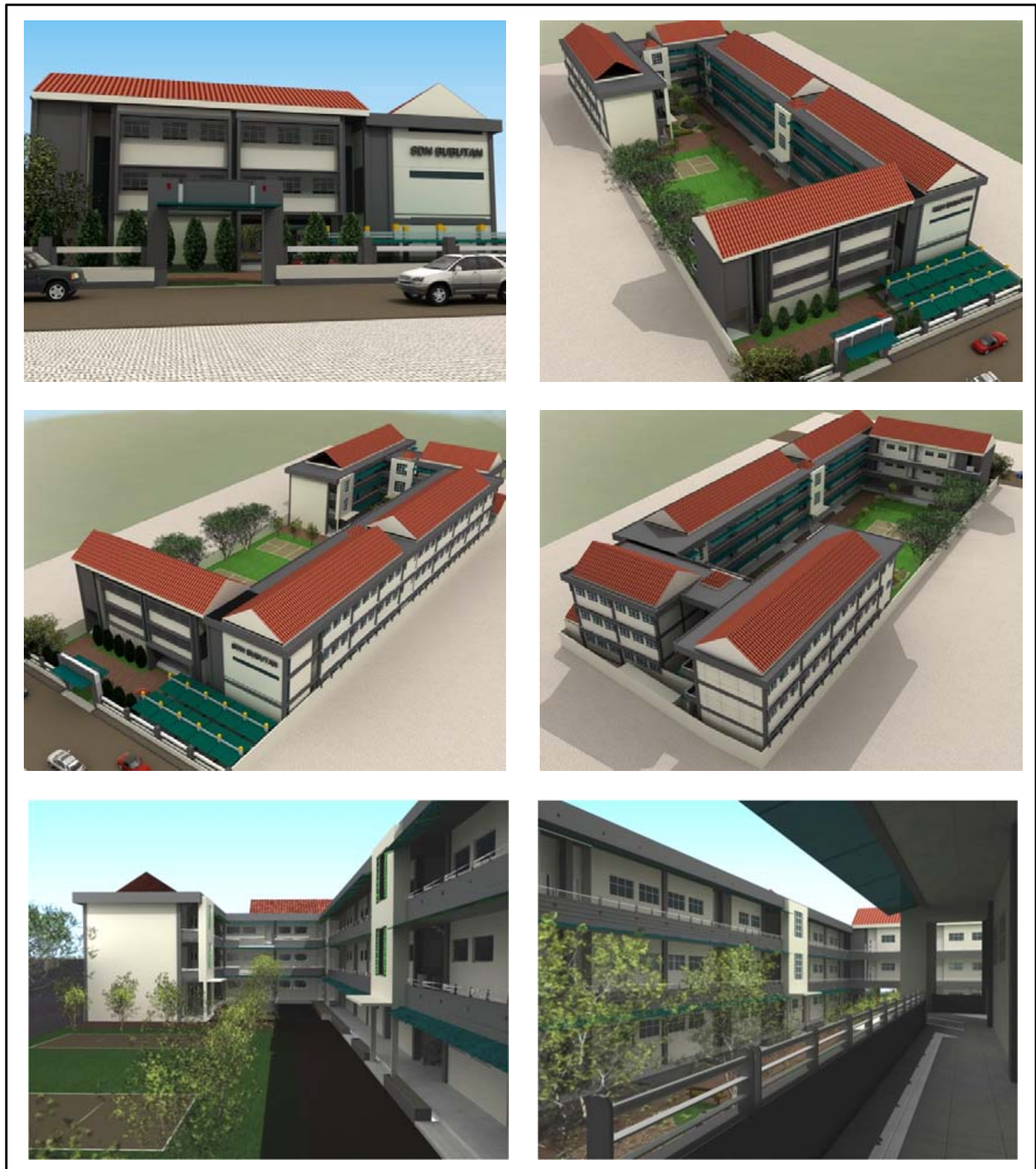

Gambar 8. Gambar visual perspektif 3D perencanaan SDN Bubutan IV Surabaya. Sumber: Dokumen pribadi (2008)

\section{E. Evaluasi Lapangan}

Perencanaan Gedung SDN Bubutan IV Surabaya di rancang pada tahun 2008, dan baru dilaksanakan pada beberapa tahun berikutnya. Selama proses pembangunan tentu terdapat penyesuaian di lapangan, namun tidak merubah keseluruhan detail. Saat ini perencanaan 
gedung telah dibangun seluruhnya. Berikut adalah gambar gedung SDN Bubutan IV Surabaya, seperti dibawah ini:

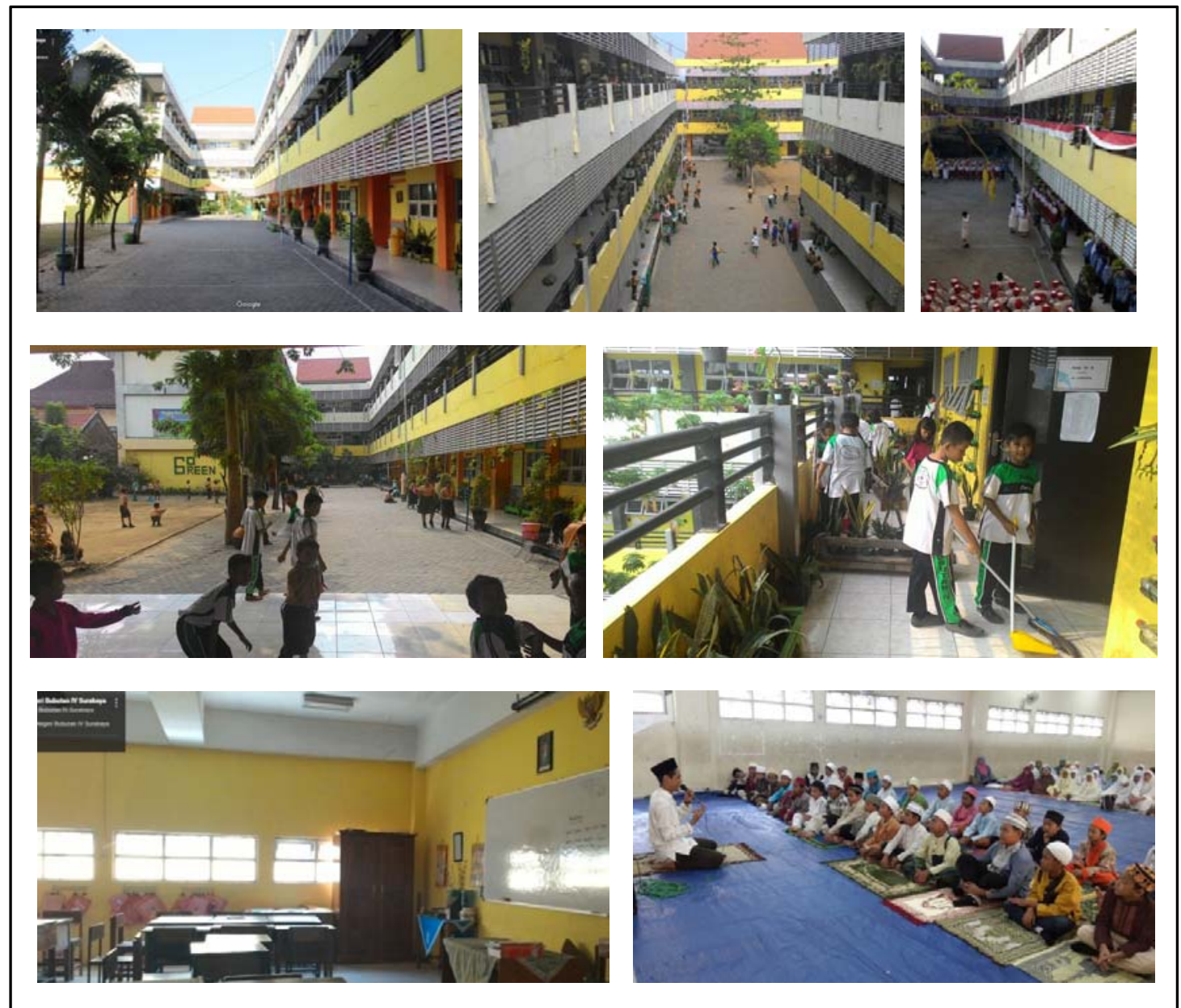

Gambar 9. Aktifitas siswa di gedung SDN Bubutan IV Surabaya sesuai dengan perencanaan. Sumber : Citra satelit google map (November, 2015)

Berdasarkan kumpulan foto kegiatan di SDN Bubutan IV Surabaya melalui website resminya, sasaran perencanaan telah tercapai, antara lain:

1. Ruang kelas dapat disusun melebihi target, dimana direncanakan untuk 32 siswa dan ternyata dapat di tata untuk 40 siswa. Lay out ruang kelas dapat berbentuk seminar dan berkelompok,

2. Posisi jendela memberikan masukan sinar matahari yang baik, sehingga ruangan cukup terang tanpa harus menyalakan lampu. Dinding dibawah jendela dapat dimanfaatkan untuk memajang tugas dan karya,

3. Tinggi railing pagar pengaman di lantai dua dan tiga dapat menjamin keamanan aktifitas siswa,

4. Area bermain dan area olahraga dapat dimanfaatkan dengan optimal. 


\section{KESIMPULAN}

Proses perencanaan pembangunan gedung sarana dan prasarana pendidikan harus memperhatikan :

1. Perencanaan mengakomodasi kebutuhan pengguna dan rencana pengembangan 10 tahun kedepan, peraturan pemerintah yang berlaku dan ergonomi - antropometri pengguna,

2. Data ergonomi dan antropometri yang ada pada umumnya dari negara Eropa, sehingga dapat menggunakan ukuran percentile $50 \%$,

3. Desain perencanaan sebaiknya memperhatikan lingkungan sekitar, karena dapat membantu perencaaan yang ramah lingkungan dan hemat energi,

4. Wajar apabila pada pelaksanaan pembangunan berbeda dari gambar perencanaan, karena menyesuaikan kondisi di lapangan dan kebutuhan yang baru dari pengguna, asalkan tidak merubah total konsep desain.

\section{PUSTAKA}

Kemdikbud Pemkot Surabaya. (2016). Profil Sekolah. Tersedia: http://sekolah.data.kemdikbud.go.id

Kementerian Pendidikan RI. (2007). Peraturan Menteri Pendidikan Nasional RI Nomor 24 tahun 2007 tentang Standar Sarana dan Prasarana Untuk Sekolah Dasar/Madrasah Ibtidaiyah (SD/MI), Sekolah Menengah Pertama/Madrasah Tsanawiyah (SMP/MTs) dan Sekolah Menengah Atas/Madrasah Aliyah (SMA/MA). Jakarta:

Kroemer, K. H. E. (2006). “Extra-ordinary” Ergonomics: how to accommodate small and big persons, the disabled and elderly, expectant mothers, and children. NW: CRC Press.

Pheasant, Stephen. (2003). Bodyspace : Anthropometry, Ergonomics and the Design of Work, 2nd Edition. UK: Taylor \& Francis Ltd.

Tilley, R. Alvin. (2002). The Measure of Man and Woman. Human Factors in Design, Revised Edition. NY: John Willey \& S 
Lea Kristina Anggraeni

Kajian Penerapan Ergonomi dalam Perancangan Bangunan Sekolah Dasar, Studi Kasus SDN Bubutan IV Surabaya 